\title{
PEMANFAATAN ABU SEKAM PADI DALAM INOVASI PEMUPUKAN KACANG HIJAU (Vigna radiate L) DI LAHAN GAMBUT
}

\author{
Yoyon Riono ${ }^{1}$, Mulono Apriyanto ${ }^{2}$ \\ ${ }^{1}$ Program Studi Agroteknologi, Universitas Islam Indragiri \\ 2Program Studi Teknologi Pangan, Universitas Islam Indragiri \\ Email: yoyonriono353@gmail.com (korespondensi)
}

\begin{abstract}
This study aimed to determine the effect of rice husk ash on yield and growth of peanut plants. This research has been carried out in the experimental garden of the Faculty of Agriculture of the Islamic University of Indragiri Tembilahan, Tembilahan Hulu District, Indragiri Hilir Regency. The time of the study began from April to July 2017. This research was a field trial using the Randomized Block Design (RBD) method which consisted of 6 levels of treatment, they are; without rice husk ash, 1 ton/ha of rice husk ash, 2 tons/ha of rice husk ash, 3 tons/ha of rice husk, 4 tons/ha ash rice husk ash, and 5 tons/ha of rice husk ash. Each treatment was repeated three times to obtain 18 trial plots in the field. Data of this study were analyzed using Analysis of Variance (ANOVA). The results showed that the administration of rice husk ash with various treatment doses, had a significant influence on the growth and yield of peanut plants. The treatment that has the best effect on the growth and yield of peanut plants has been found, which is an average of 3 tons/ha and 5 tons/ha.
\end{abstract}

Keywords: Rice husk ash, Peanuts, Peat.

\begin{abstract}
Abstrak
Penelitian ini bertujuan untuk mengetahui pengaruh abu sekam padi terhadap hasil dan pertumbuhan tanaman kacang tanah. Penelitian ini telah dilaksanakan di kebun percobaan fakultas pertanian universitas islam indragiri tembilahan, Kecamatan tembilahan hulu, Kabupaten Indragiri Hilir. Waktu penelitian dimulai dari bulan April sampai Juli 2017. Penelitian ini merupakan percobaan lapangan menggunakan metode Rancangan Acak Kelompok (RAK) yang terdiri atas 6 taraf perlakuan yaitu tanpa abu sekam padi, abu sekam padi 1 ton/ha, abu sekam padi 2 ton/ha, abu sekam padi 3 ton/ha abu sekam padi 4 ton/ha, abu sekam padi 5 ton/ha. Setiap perlakuan di ulang tiga kali sehingga diperoleh 18 petakpetak percobaan di lapangan. Data hasil penelitian ini dianalisis dengan menggunakan Analysis Of Variance (ANOVA). Hasil penelitian menunjukkan bahwa pemberian abu sekam padi dengan berbagai dosis perlakuan, sudah memberikan pengaruh nyata terhadap pertumbuhan dan hasil tanaman kacang tanah. Sudah ditemukan perlakuan yang memberikan pengaruh terbaik terhadap pertumbuhan dan hasil tanaman kacang tanah yaitu rata-rata 3 ton/ha dan 5 ton/ha.
\end{abstract}

Kata kunci: Abu sekam padi, Kacang Hijau, Gambut

\section{PENDAhULUAN}

Tanaman kacang hijau (Vigna radiate L. ) sudah lama dikenal dan ditanam oleh masyarakat tani indonesia. Asal usul tanaman kacang hijau berasal dari kawasan india yang dibawa masuk ke wilayah indonesia, terjadi pada awal abad ke-17, oleh pedagang Cina. Pusat penyebaran kacang hijau pada mulanya berpusat pulau jawa dan bali, tetapi pada tahun 1920-an mulai berkembang di Sulawesi, Kalimantan, dan Indonesia bagian timur ( Rukmana, 2002). Kacang hijau (Vigna radiata L.) merupakan salah satu komoditas tanaman kacang-kacangan yang banyak dikonsumsi rakyat Indonesia, seperti: bubur kacang hijau dan isi onde-onde. Kecambahnya dikenal sebagai tauge. Manfaat lain dari tanaman ini adalah dapat melancarkan buang air besar dan menambah semangat hidup, juga digunakan untuk pengobatan (Atman, 2007)

Kacang hijau memiliki beberapa kelebihan dibandingkan tanaman pangan lainnya, yaitu berumur genjah, lebih toleran kekeringan, dapat ditanam pada lahan yang kurang subur, cara budidayanya mudah, dan hama yang menyerang relatif sedikit (Kasno 2007). Produksi kacang hijau sebagai salah 
satu bahan pangan masih perlu ditingkatkan sejalan dengan bertambahnya jumlah penduduk. Peningkatan permintaan dicerminkan dari adanya kecenderungan meningkatnya kebutuhan untuk memenuhi konsumsi langsung dan pasokan bahan baku untuk industri pangan di hilirnya (Direktorat Budidaya Aneka Kacang dan Umbi 2013). Luas areal tanam/panen kacang hijau sekitar 229. 475 ha dengan produktivitas rendah, Yakni 1,18 t/ha (BPS 2016). Rendahnya tingkat produktivitas tersebut antara lain disebabkan oleh pemupukan yang kurang optimal dan varietas yang produktivitasnya rendah.

Permintaan terhadap kacang hijau cukup tinggi dan cenderung meningkat dari tahun ketahun, sementara peningkatan laju luas areal tanamannya masih dibawah jagung dan kedelai. Kandungan gizi kacang hijau meliputi karbohidrat $62,90 \mathrm{gr}$, protein 20,00 gr, lemak 1,20 gr, juga mengandung Vitamin A 157,00 SI, Vitamin B1 0,64 gr, Vitamin C 6,00 gr dan mineral $\mathrm{Ca}, \mathrm{P}, \mathrm{Fe}$ serta mengandung 345 gr kalori (Rukmana, 2002).

Budidaya yang baik salah satu cara budidaya yang baik dengan mengunakan media tanam yang sesuai dengan kebutuhan tanaman. Salah satu tanah yang strukturnya lembut dan remah dan banyak mengandung air adalah tanah gambut. Tanah gambut mengandung unsur mikro yang sangat rendah dan diikat cukup kuat oleh bahan organik terutama $\mathrm{Cu}$, Bo dan $\mathrm{Zn}$ sehingga tidak tersedia bagi tanaman. Selain itu adanya kondisi reduksi yang kuat menyebabkan unsur mikro direkduksi ke bentuk yang tidak dapat diserap tanaman. Ketersediaan unsur hara mikro pada tanah gambut dapat ditingkatkan dengan pemberian amelioran. Pemberian amelioran pada tanah gambut bertujuan untuk meningkatkan pH dan basa - basa tanah serta memperbaiki komplek absorpsi tanah gambut (Subika, dkk 1997 ; Mario, 2002).

Ameliorasi tanah gambut bertujuan untuk memperbaiki sifat fisik dan kimia tanah sehingga produktivitas lahan meningkat, salah satu bahan ameliorant yang dapat digunakan adalah abu. Salah satu jenis abu yang biasa digunakan sebagai amelioran adalah abu sekam. Abu sekam dapat diperoleh dari sisa hasil bakaran di dapur, pembakaran sisa hasil pertanian sampah rumah tangga, dan limbah gergaji kayu. Ditinjau dari deposit dan kandungan hara yang terkandung dalam abu sekam adalah $\mathrm{Fe}, \mathrm{Al}, \mathrm{Ca}, \mathrm{Mg}, \mathrm{Mn}, \mathrm{Cu}, \mathrm{Zn}, \mathrm{Ti}$ dan $\mathrm{Si}$, pengunaan abu sebagai bahan amelorian pada lahan gambut cukup menjanjikan, dosis abu sekam sebagai amelioran di lahan gambut sekitar 10 ton ha (Setiadi, 2008).

Peningkatan produksi kacang hijau juga dapat dilakukan dengan cara penggunaan pupuk yang efisien dan melakukan teknik budaya tanaman kacang hijau yang baik untuk mendapatkan hasil tanaman kacang hijau yang optimum ( Cahyono, 2007).

Penggunaan pupuk merupakan suatu kebutuhan bagi tanaman dalam hal mencukupi kebutuhan nutrisi dan menjaga keseimbangan hara yang tersedia selama siklus pertumbuhan tanaman. Pemberian pupuk anorganik merupakan tindakan pengelolaan yang diharapkan dapat memperbaiki sifat kimia, sehingga kesuburan tanah dapat ditingkatkan Setyamidjaja, 1990).

Gambut merupakan salah satu jenis tanah dengan luas lahan yang cukup besar dan sangat potensial dikembangkan dalam kegiatan pertanian hortikultura. Gambut memiliki potensi kandungan bahan organik tinggi dan kemampuan menyerap air tinggi yaitu 13 kali dari beratnya. Namun, permasalahan pengembangan pertanian di tanah gambut menjadi kendala utama dalam pengembangan pertanian. Kendala pertanian pada tanah gambut sesungguhnya disebabkan oleh drainaise jelek, kemasaman tinggi, tingkat kesuburan dan kerapatan lindak rendah. Kemasaman gambut yang tinggi dan ketersediaan hara serta Kejenuhan Basah (KB) rendah menyebabkan pertumbuhan dan perkembangan tanaman sangat rendah.

Kombinasi 5 ton pupuk kandang dengan 2 ton abu sekam/ha dapat meningkatkan hasil biji kedelai tertinggi, dan abu sekam padi dengan dosis 2 ton/ha mempunyai pengaruh yang sama dengan $\mathrm{KCl}$ dosis 150 $\mathrm{kg} / \mathrm{ha}$. Pemberian abu jerami padi dengan takaran 54 gram per tanaman pada tanaman merupakan takaran abu jerami yang terbaik untuk pertumbuhan dan hasil umbi tanaman kedelai. Berdasarkan penelitian ini dianjurkan untuk melakukan pemberian abu jerami padi sebagai sumber hara kalium untuk menaikkan produksi umbi tanaman ubi jalar dengan takaran 54 gram per tanaman (Djalil et al., 2004).

Berdasarkan permasalahan yang telah diuraikan diatas maka perlu dilakukan penelitian "Pemanfaatan Abu Sekam Padi dalam Inovasi Pemupukan Kacang Hijau (Vigna radiate $\mathrm{L}$ ) di Lahan Gambut"

\section{TINJAUAN PUSTAKA \\ 2.1. Morfologi}

Menurut Rukmana (2002), Tanaman kacang hijau termasuk tanaman semusim 


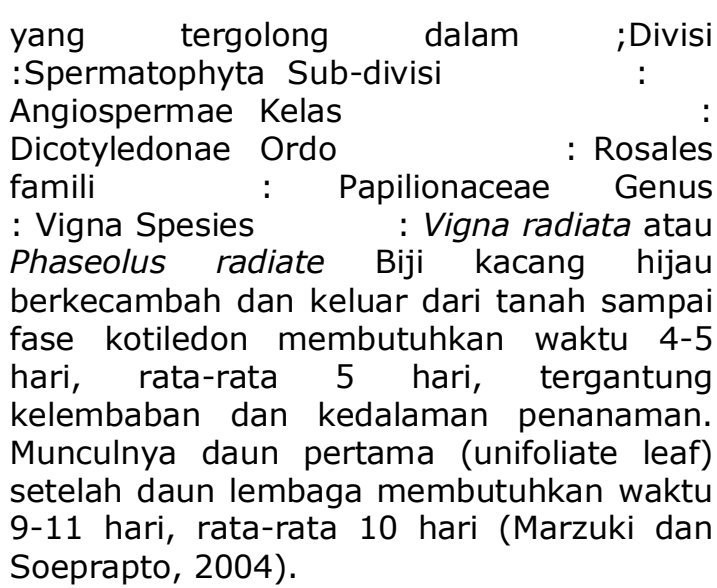

\subsubsection{Akar}

Tanaman kacang hijau berakar tunggang. Sistem perakarannya dibagi menjadi dua yaitu mesophytes dan xerophytes. Perakaran tanaman kacang hijau bercabang banyak dan membentuk bintil-bintil (nodula) akar (Rukmana, 1997).

Perakaran tanaman kacang hijau tersusun atas akar tunggang dan akar lateral. Akar tunggang merupakan akar primer yang tumbuh paling awal dari benih yang tumbuh. Akar tunggang mempunyai panjang lebih kurang 1 meter dengan lebar mencapai $40 \mathrm{~cm}$ lebih. (Cahyono, 2007).

\subsubsection{Batang}

\section{Batang}

tanaman kacang hijau berukuran kecil, berbulu, berwarna hijau kecokelat-cokelatan, atau kemerahmerahan; tumbuh tegak mencapai ketinggian $30 \mathrm{~cm}-110 \mathrm{~cm}$ dan bercabang menyebar ke semua arah. Daun tumbuh majemuk, tiga helai anak daun per tangkai. Helai daun berbentuk oval dengan ujung lancip dan berwarna hijau (Andrianto dan Indiarto, 2004).

\subsubsection{Daun}

Tanaman kacang hijau berdaun majemuk yang tersusun dari tiga helaian (trifoliate) anak daun setiap tangkai. Dau berbentuk lonjong dengan bagian ujung berbentuk runcing (Cahyono, 2007). Daun tanaman kacang hijau terdiri dari 3 helaian (trifoliat) dan letaknya bersilang. Tangkai daunnya cukup panjang dari daun. Daunnya berwarna hijau muda sampai hijau tua (Andrianto dan Indiarto, 2004).

\subsubsection{Bunga}

Bunga tanaman kacang panjang berbentuk kupu-kupu dengan mahkota bunga berwarna kuning keabu-abuan atau kuning muda tergantung pada varietasnya. Bunga ini termasuk bunga sempurna atau berkelamin dua (hermaphrodid), yaitu setiap bunga terdapat benang sari (sel kelamin jantan) dan kepala putik (kelamin betina) (Cahyono, 2007).

Bunga kacang hijau berkelamin sempurna (hermaphrodite), berbentuk kupu-kupu, dan berwarna kuning. Buah berpolong, panjangnya antara $6 \mathrm{~cm}-15$ $\mathrm{cm}$. Tiap polong berisi $6-16$ butir biji. Biji kacang hijau berbentuk bulat kecil dengan bobot (berat) tiap butir $0,5 \mathrm{mg}-0,8 \mathrm{mg}$ atau per 1000 butir antara $36 \mathrm{~g}-78 \mathrm{~g}$, berwarna hijau sampai hijau mengilap. Biji kacang hijau tersusun atas tiga bagian, yaitu kulit biji, kotiledon, dan embrio (Rukmana, 1997).

\subsubsection{Buah (polong)}

Buah kacang hijau berbentuk polong (sillindris) dengan panjang antara6-15 cm, berbulu pendek, polong kacang hijau bersekmen-sekmen yang berisi biji. Sewaktu muda polong berwarna hijau dan setelah tua berwarna hitam coklat. Setiap polong berisi 10-15 biji. Biji kacang hijau lebih kecil dibanding kacang- kacangan lain. Warna bijinya kebanyakan hiaju kusam atau hijau mengkilap, beberapa ada berwarna kuning, coklat dan hitam (Rukmana, 2002).

\subsubsection{Biji}

Biji berbentuk bulat kecil berwarna hijau sampai hijau gelap. Warna tersebut merupakan warna dari kulit bijinya. Biji kacang hijau berkeping dua dan terbungkus oleh kulit. Bagian-bagian biji terdiri dari kulit, keping biji, pusar biji (hilum) dan embrio yang terletak diantara keping biji. Pusar biji atau hilium merupakan jaringan bekas biji melekat pada dinding buah. Keping biji mengandung makanan yang akan digunakan sebagai makanan calon tanaman yang akan tumbuh (Cahyono, 2007).

\subsection{Syarat Tumbuh Tanaman Kacang Hijau \\ 2.2.1. Iklim}

Kacang hijau termasuk tanaman tropis yang menghendaki suasana panas selama hidupnya.Tanaman ini dapat tumbuh baik didaerah dataran rendah hingga ketinggian 500 mdpl. Kondisi lingkungan yang di kehendaki tanaman kacang hijau adalah daerah bersuhu $20^{\circ}$ $27^{\circ} \mathrm{C}$, kelembaban udara antara $50 \%-70 \%$ dan cukup mendapat sinar mata hari. Curah hujan yang dikehendaki berkisar antara 20-50 $\mathrm{mm}$ perbulan (Rukmana, 2002). Jumlah curah hujan dapat mempengaruhi produksi kacang hijau. Tanaman ini cocok ditanaman pada musim kering (kemarau) yang rataan curah 
hujannya rendah (Rukmana, 1997).

\subsubsection{Tanah}

Jenis tanah yang dikehendaki tanaman kacang hijau adalah liat berlempung atau tanah lempung yang banyak mengandung bahan organik. Kacang hijau dapat tumbuh pada ketinggian < $2000 \mathrm{~m} \mathrm{dpl,} \mathrm{dan} \mathrm{tumbuh}$ subur pada tanah liat atau liat (Andrianto dan Indiarto, 2004).

Kacang hijau dapat tumbuh disegala macam jenis tanah yang berdrainase baik. Namun, pertumbuhan terbaiknya pada tanah lempung biasa sampai yang mempunyai bahan organik tinggi. Tanah yang mempunyai ph 5,8 paling ideal untuk pertumbuhan kacang hijau. Sedangkan tanah yang sangat asam tidak baik karena penyediaan unsur hara terhambat. Kacang hijau menghendaki tanah dengan kandungan hara (fosfor, kalium, kalsium, maknesium, dan belerang) yang cukup. Unsur hara ini penting untuk meningkatkan produksinya (Cahyono, 2007).

Tanah merupakan media tanam yang paling umum digunakan dan sebagai bahan campuran media tanam utama, tetapi masih diperlukan bahan organik sebagai campuran medianya agar tanaman dapat tumbuh dengan baik (Yushanita, 2007).

Tanah merupakan hasil pelapukan dari batuan. Jenis tanah dibedakan menjadi dua, yaitu tanah mineral dan tanah organik. Tanah mineral adalah tanah yang merupakan hasil pelapukan dari bahanbahan mineral, sedangkan tanah organik adalah tanah yang berasal dari hasil pelapukan bahan-bahan organik. Tanah orga- nik memiliki bahan organik dalam jumlah yang tinggi, misalnya tanah gambut. Setiap jenis tanah memiliki sifat fisik dan sifat kimia yang berbeda, sebagai con- toh tanah latosol memiliki sifat kimia yang kurang baik, memiliki KTK yang rendah disebabkan oleh bahan organik sedikit dan memerlukan tambahan unsur hara $\mathrm{N}$, $\mathrm{P}, \mathrm{K}, \mathrm{Ca}, \mathrm{Mg}$ dan beberapa unsur mikro (Murbandono, 1994).

\subsubsection{Sekam padi}

Merupakan lapisan keras yang meliputi kariopsis yang terdiri dari dua bentuk daun yaitu sekam kelopak dan sekam mahkota. Pada proses penggilingan padi, sekam akan terpisah dari butir beras dan menjadi bahan sisa atau limbah penggilingan (Aziz, 1992). Sekam tersusun dari jaringan serat-serat selulosa yang mengandung banyak silika dalam bentuk serabut-serabut yang sangat keras (Nuryono dan Narsito, 2009). Gambar 2 menunjukkan sekam padi dari limbah penggilingan padi.
Pada keadaan normal, sekam berperan penting melindungi biji beras dari kerusakan yang disebabkan oleh serangan jamur secara tidak langsung, melindungi biji, dan juga menjadi penghalang terhadap penyusupan jamur. Selain itu sekam juga dapat mencegah bau yang tidak sedap (tengik) karena dapat melindungi lapisan tipis yang kaya minyak terhadap kerusakan mekanis selama pemanenan, penggilingan dan pengangkutan (Haryadi, 2006). Dari proses penggilingan padi biasanya diperoleh sekam sekitar 20-30\% dari bobot gabah (Deptan, 2011)

\subsubsection{Abu Sekam Padi}

Abu sekam padi merupakan limbah yang diperoleh dari hasil pembakaran sekam padi. Bila abu sekam padi dibakar pada suhu terkontrol, abu sekam yang dihasilkan dari sisa pembakaran mempunyai sifat pozzolan yang tinggi karena mengandung silika. Abu sekam memiliki fungsi mengikat logam berat. Selain itu sekam berfungsi untuk menggemburkan tanah sehingga bisa mempermudah akar tanaman untuk menyerap unsur hara di dalam tanah. Keuntungan menggunakan sekam bakar adalah steril, poros, banyak unsur hara, ringan untuk mobilisasi. Abu sekam merupakan bahan organik dan merupakan kompos bagi tanah, dimana bahan organik akan berfungsi memperbaiki sifat tanah dan membantu mengikat unsur nitrogen, fospor, dan kalium dalam tanah agar tidak hilang karena kalau unsur tersebut hilang, tanaman akan kekurangan unsur hara. Abu sekam padi dapat digunakan untuk memperbaiki struktur tanah. Penggunaan sekam padi juga akan memperbaiki sifat fisik tanah dengan mengurangi kepadatan tanah (Hara, 1986).

Abu Sekam adalah bagian terluar dari bulir padi, yang merupakan hasil sampingan saat proses penggilingan padi dilakukan. Sekitar $20 \%$ dari bobot padi adalah sekam padi dan kurang lebih $15 \%$ dari komposisi sekam adalah abu sekam yang selalu dihasilkan setiap kali sekam dibakar (Harsono, 2002). Sutanto (2002) menambahkan bahwa sekam padi secara nyata mempengaruhi sifat kimia, fisik, dan biologi tanah.

Penggunaan abu sekam pada lahan pertanian selain sebagai sumber silikat juga merupakan salah satu alternatif untuk mengurangi pencemaran lingkungan oleh limbah pertanian di sekitar lokasi penggilingan padi dan sekaligus sebagai upaya pengembalian sisa panen ke areal pertanian. Pemberian abu sekam sebagai sumber silikat pada tanah gambut yang 
dapat menetralisi keasaman tanah (Ilyas et al., 2000).

Mineralisasi sekam padi akan melepaskan hara secara lambat dan kontinyu sehingga hara akan tersedia dalam jangka waktu yang panjang. Hasil analisis yang dilakukan oleh Soepardi et al. (1982) diperoleh data bahwa sekam padi mengandung $0.46 \% \mathrm{~N}$ total, $0.04 \%$ P, $0.37 \%$ K, $0.26 \%$ Ca, 0.05 \% $\mathrm{Mg}$, dan $17.80 \%$ Si. Abu sekam mengandung $0.30 \% \mathrm{~N}, 0.13 \% \mathrm{P}, 0.88 \%$ $\mathrm{K}, 0.28 \% \mathrm{Ca}, 0.02 \% \mathrm{Mg}$, dan $87.28 \% \mathrm{Si}$. Sutanto (2002) menyatakan bahwa sekam padi memiliki kandungan lengas $9.02 \%$, protein jenuh $3.27 \%$, lemak $1.18 \%$, karbohidrat $33.71 \%$, serat jenuh $35.68 \%$, dan abu $17.71 \%$

\section{METODOLOGI PENELITIAN}

\subsection{Tempat dan Waktu Penelitian}

Penelitian ini akan dilaksanakan di Jalan Bersama parit 10 Tembilahan Kota, Kabupaten Indragiri Hilir Propinsi Riau, penelitian ini dilaksanakan selama tiga bulan terhitung dari bulan Maret sampai dengan Mei 2019

\subsection{Bahan dan Alat}

Bahan yang digunakan dalam penelitian ini adalah benih kacang hijau yang diperoleh dari toko pertanian, Abu Sekam Padi, Fungisida Dithane M-45, Insektisida Furudan 3GR dan bahan- bahan lain yang mendukung dalam penelitian ini

Alat-alat yang digunakan yaitu cangkul, meteran, penggaris, parang, ajir, papan nama perlakuan, tugal, timbangan, hand sprayer, alat tulis, gunting, plang perlakuan, tali rafiah, plastik dan gembor,kamera.

\subsection{Rancangan Penelitian}

Penelitian ini dilakukan dengan menggunakan Rancangan Acak Kelompok (RAK non factorial) dengan 6 perlakuan dan 3 kelompok sehingga terdapat 18 plot. Pada masing-masing plot terdiri dari 9 tanaman dan 6 tanaman sampel perplot. Tanaman sampel diambil dari petak umbian.

$\mathrm{H} 1$ = Abu Sekam Padi 1 ton/ha

H 2 = Abu Sekam Padi 2 Ton/ha

H 3 = Abu Sekam Padi 3 Ton/ha

$\mathrm{H} 4$ = Abu Sekam Padi 4 Ton/ha

H 5 = Abu Sekam Padi 5 Ton/ha

H 6 = Abu Sekam Padi 6 Ton/ha

Hasil penelitian dianalisis dengan menggunakan sidik ragam Turkey HSD taraf $5 \%$ berdasarkan model linier sebagai berikut:

$Y i j=\mu+T i+\varepsilon i j$

Yij = Hasil pengamatan pada perlakuan ke-i

dan ulangan ke-j

$\mu=$ rataan umum
$\mathrm{Ti}=$ pengaruh perlakuan ke-i

$\varepsilon \mathrm{ij}=$ pengaruh acak pada perlakuan ke-I ulangan ke-j

\subsection{Pelaksanaan Penelitian \\ 3.4.1 Persiapan Lahan}

Persiapan dan pembersihan lahan terhadap berbagai jenis gulma dan sisa tanaman kemudian dikumpulkan menjadi satu lalu dibuang dan dibakar diluar lahan penelitian kemudian dilakukan pengolahan tanah tahap pertama. Pengolahan kedua adalah Pembuatan plot sebanyak 18 plot dengan ukuran $100 \mathrm{~cm}$ x $100 \mathrm{~cm}$ dengan jarak antar plot $50 \mathrm{~cm}$.

\subsubsection{Pemasangan Label}

Label yang telah disiapkan dipasang sesuai dengan perlakuan masing-masing pada plot yang telah disiapkan kemudian disesuaikan dengan lay out penelitian di lapangan. Pemasangan label dilakukan satu hari sebelum pemberian perlakuan.

\subsubsection{Perlakuan}

1. Pemberian Abu Sekam Padi

Pemberian abu sekam padi dilakukan pada saat satu minggu sebelum tanam diberikan sesuai dengan perlakuan masingmasing. Pemberian abu sekam padi dilakukan satu kali dengan cara menabur di dalam setiap plot.

2. Pemberian Pupuk NPK Mutiara

Pemberian pupuk NPK Mutiara dilakukan pada saat tanam diberikan sesuai perlakukan masing-masing dengan cara ditugal dengan jarak $3 \mathrm{~cm}$ dari lubang tanam. Pemberian pupuk NPK Mutiara dilakukan satu kali.

\subsubsection{Penanaman}

Benih kacang hijau yang akan ditanaman sebelumnya diseleksi dengan cara merendam bibit sebelum penanaman, bibit yang mengapung keatas tidak ditanam melainkan bibit yang tenggelam didalam air yang ditanam di plot penelitian bertujan untuk megantisipasi benih yang tidak bagus . Jarak tanam yang digunakan $20 \mathrm{~cm}$ x 20 $\mathrm{cm}$ dengan 1 butir benih perlubang tanam. Kedalaman lubang tanam sekitar $3 \mathrm{~cm}$.

\subsubsection{Pemeliharaan}

1. Penyiraman

Penyiraman dilakukan dua kali dalam satu hari yaitu pada waktu pagi dan sore hari, jika turun hujan tidak dilakukan. Penyiraman bertujuan agar kelembaban tanah di sekitar daerah perakaran tetap terjaga dan penyiraman dilakukan dengan menggunakan gembor.

2. Penyiangan

Penyiangan gulma dilakukan saat tanaman berumur dua minggu dengan menggunakan tangan dan penyiangan 
dilakukan pada sore hari. Penyiangan dilakukan dengan cara mencabut gulma yang tumbuh disekitar tanaman. Penyiangan dilakukan dengan interval dua minggu.

3. Pengendalian Hama dan Penyakit

Pengendaian hama dan penyakit dilakukan dengan menyemprotkan fungisida Dithen M-45 dan insektisida furudan 3GR untuk pencegahan jamur dan serangga dilakukan seminggu setelah tanam. Dan dilakukan penyemprotan kembali jika ada serangan dari hama dan penyakit yang menyerang tanaman.

4. Panen (hari)

Panen kacang hijau dapat dilakukan secara serempak, $\geq 50 \%$ dari populasi menunjukan kiteria panen polong berwarna cokelat atau hitam dan masih utuh. Waktu panen dilakukan pada saat pagi atau sore hari untuk menjaga supaya polong tidak pecah, pemanenan kacang hijau dilakukan beberapa kali sampai ahir masa panen.

\subsection{Parameter Pengamatan}

Parameter yang diamati dalam penelitian ini antara lain:

\subsubsection{Tinggi Tanaman (cm)}

Pengukuran tinggi tanaman dilakukan pada ahair masa panen, pengukuran dari bagian pangkal batang (permukaan tanah) sampai ke titik tumbuh tanaman kacang hijau. Pengukuran dengan menggunakan meteran.

\subsubsection{Jumlah Polong Pertanaman (polong)}

Pengamatan jumblah polong dilakukan dengan cara menghitung jumlah polog pada setiap tanaman sampel, dengan meghitug jumblah polong berisi dan jumblah polong hampa. Pengamatan ini dilakukan pada saat pemanenan.

\subsubsection{Persentasi Polong Bernas}

Pengamatan ini dilakukan dengan cara menghitung jumlah polong bernas, dengan kereteria apabila didalam satu polong terdapat minimal satu polong bernas maka polong tersebut sudah termasuk kedalam katagori polong bernas, pengamatan ini dilakukan pada tanaman sampel.

\subsubsection{Panjang Polong (cm)}

Pengukuran panjang polong dilakukan pada setiap plot perlakuan dan sampel diambil sebanyak 5 polong.

\subsubsection{Produksi Per Plot}

Hasil produksi perplot diambil dari setiap plot masing-masing perlakuan dengan cara menimbang semua hasil produksi.

\subsubsection{Berat 1000 biji basah (gram)}

Penimbangan dilakukan dengan menimbang berat 1000 biji basah per perlakuan Data yang di peroleh di konversikan dengan mengunakan rumus :

$$
\breve{y} \pm \frac{\sum x_{2}}{n(n-1)}
$$

Keterangan

$\bar{y}$ : berat rata-rata 1000 butir benih

$\mathrm{n}$ : ulangan

$x$ :selisih berat rata-rata 1000 butir pada masing-masing ulangan

\section{HASIL DAN PEMBAHASAN}

\subsection{Tinggi Tanaman (cm)}

Analisis sidik ragam (Lampiran ) menunjukan bahwa perlakuan Abu Sekam Padi berpengaruh nyata terhadap tinggi tanaman. Hasil uji lanjut dengan Tukey HSD taraf terkecil $5 \%$ pengamatan tinggi tanaman dapat dilihat pada tabel 1

Tabel 1 . Hasil dan Pertumbuhan Tanaman Kacang Hijau (Vigna radiata $L$ ) terhadap pemberian Abu Sekam Padi di lahan Gambut

\begin{tabular}{ll}
\hline Perlakuan & Tinggi Tanaman \\
$(\mathrm{cm})$
\end{tabular}

Abu Sekam Padi 1 Ton/ha

$30.00 \mathrm{~d}$

Abu Sekam Padi 2 Ton/ha

$53.33 \mathrm{bcd}$

Abu Sekam Padi 3 Ton/ha

$80.00 \mathrm{a}$

Abu Sekam Padi 4 Ton/ha

$73.33 \mathrm{ab}$

Abu Sekam Padi 5 Ton/ha

$60.00 \mathrm{abc}$

Abu Sekam Padi 6 Ton/ha $40.00 \mathrm{~cd}$

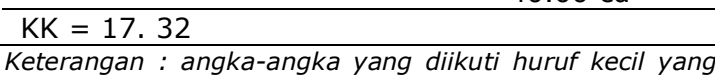
tidak sama menunjukan berbeda nyata pada taraf $5 \%$ menurut uji Tukey HSD

Tabel 1 menujukan bahwa hasil pengamatan rerata tinggi tanaman untuk semua perlakuan dengan berbagai konsentrasi berkisar 30,00-80,00 cm. Tinggi tanaman yang terendah pada perlakuan Abu Sekam Padi 1 ton/ha yaitu sebesar 30,00 $\mathrm{cm}$, sedangkan tinggi tanaman yang tertinggi diperoleh pada perlakuan Abu Sekam Padi 3 ton/ha yaitu sebesar 80,00 $\mathrm{cm}$. Hal ini dikarenakan kandugan unsur hara yang ada didalam abu sekam padi seperti unsur hara makro N, P, K, dan unsur mikro dapat mempercepat pertumbuhan secara optimal sehingga mempengaruhi pada tinngi tanaman

Pengaruh pemberian sekam padi terhadap tinggi tanaman berhubungan erat dengan adanya perbaikan kondisi tanah dan ketersediaan unsur- unsur hara bagi kebutuhan kacang hijau. Hal ini disebabkan 
adanya sumbangan unsur hara makro (Unsur N, P, K, Ca, Mg) maupun unsur hara mikro ( $\mathrm{Cu}, \mathrm{Zn}, \mathrm{Mn}$, dan Fe) dari sekam padi bagi tinggi tanaman. Secara umum unsur $P$ berfungsi antara lain untuk memperkuat pertumbuhan seperti tinggi tanaman dan mempercepat pembungaan serta pemasakan buah. Tersedianya fosfor sangat penting dalam pembentukan ATP (Adenosin Triphospate) yang merupakan sumber energi bagi tanaman untuk penyerapan hara mineral (Fadli, 2015).

\subsection{Jumlah \\ (polong)}

Analisis sidik ragam (Lampiran ) menunjukan bahwa perlakuan Abu Sekam Padi berpengaruh nyata terhadap jumlah polong tanaman kacang hijau. Hasil uji lanjut dengan Tukey HSD taraf terkecil 5\% pengamatan tinggi tanaman dapat dilihat pada tabel 2

Tabel 2 . Hasil dan Pertumbuhan Tanaman Kacang Hijau (Vigna radiata $L$ ) terhadap pemberian Abu Sekam Padi di lahan Gambut

\begin{tabular}{ll}
\multicolumn{2}{c}{ Padi di lahan Gambut } \\
\hline \multirow{3}{*}{ Perlakuan } & $\begin{array}{l}\text { Jumlah } \\
\text { polong/tanaman } \\
\text { (polong) }\end{array}$
\end{tabular}

\begin{tabular}{ll}
\hline Abu Sekam Padi 1 Ton/ha & $14.33 \mathrm{e}$ \\
Abu Sekam Padi 2 Ton/ha & $17.66 \mathrm{~d}$ \\
Abu Sekam Padi 3 Ton/ha & $30.00 \mathrm{a}$ \\
Abu Sekam Padi 4 Ton/ha & $22.67 \mathrm{c}$ \\
Abu Sekam Padi 5 Ton/ha & $24.33 \mathrm{c}$ \\
Abu Sekam Padi 6 Ton/ha & $26.66 \mathrm{~b}$ \\
\hline KK
\end{tabular}

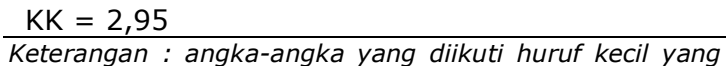
tidak sama menunjukan berbeda nyata pada taraf $5 \%$ menurut uji Tukey HSD

Tabel 2 menujukan bahwa hasil pengamatan rerata tinggi tanaman untuk semua perlakuan dengan berbagai konsentrasi berkisar 14.00-30.00 polong. Jumlah polong pertanaman tanaman kacang hijau yang terendah pada perlakuan Abu Sekam Padi 1 ton/ha yaitu sebesar 14.33 polong, sedangkan jumlah polong tertinggi tanaman yang tertinggi diperoleh pada perlakuan Abu Sekam Padi 3 ton/ha yaitu sebesar 30.00 polong $\mathrm{Hal}$ ini diduga karena abu sekam padi mampu memberikan ketersediaan unsur hara yang cukup bagi pertumbuhan generatif tanaman, karena ketersediaan unsur hara bagi pertumbuhuhan generatif tanaman mencapai titik optimum pada dosis tersebut. Pemberian abu sekam padi berpengaruh sangat nyata bila dibandingkan dengan tanpa penggunaan abu sekam, hal ini disebabkan oleh Si yang diberikan mampu meningkatkan ketersediaan $\mathrm{P}$, dengan cara menggantikan ion $\mathrm{P}$ yang terikat pada komponen tanah dengan ion $\mathrm{Si}$, sehingga $\mathrm{P}$ menjadi lebih tersedia.

Lingga (2007) menambahkan bahwa, unsur $P$ diperlukan tanaman untuk memperbanyak pertumbuhan generatif (bunga dan buah) sehingga kekurangan unsur $P$ dapat menyebabkan produksi tanaman menjadi menurun. Hal ini Sejalan dengan penelitian Suranto (2015) menyatakan bahwa pemberian abu sekam padi terhadap pertumbuhan tanaman jagung manis dapat mempercepat umur panen dikarenakan unsur $\mathrm{P}$ berperan dalam proses mempercepat pembungaan serta pemasakan biji. Selain itu unsur $P$ berfungsi dalam merangsang pertumbuhan akar-akar baru dari benih tanaman muda dan berperan dalam proses fotosintesis serta pertumbuhan tanaman.

\subsection{Persentasi Polong Bernas}

Analisis sidik ragam (Lampiran ) menunjukan bahwa perlakuan Abu Sekam Padi berpengaruh nyata terhadap persentasi polong bernas tanaman kacang hijau. Hasil uji lanjut dengan Tukey HSD taraf terkecil $5 \%$ pengamatan jumlah polong bernas tanaman dapat dilihat pada tabel

Tabel 3 . Hasil dan Pertumbuhan Tanaman Kacang Hijau (Vigna radiata L ) terhadap pemberian Abu Sekam Padi di lahan Gambut persentase polong bernas Perlakuan Jumlah polong/tanaman (polong)

Abu Sekam Padi 1 Ton/ha $75.00 \mathrm{~b}$ Abu Sekam Padi 2 Ton/ha $78.00 \mathrm{ab}$

Abu Sekam Padi 3 Ton/ha

$76.33 \mathrm{~b}$

Abu Sekam Padi 4 Ton/ha

$76.00 \mathrm{~b}$

Abu Sekam Padi 5 Ton/ha

$76.66 \mathrm{ab}$

Abu Sekam Padi 6 Ton/ha 87.66 a

$\mathrm{KK}=8,16$

Keterangan : angka-angka yang diikuti huruf kecil yang tidak sama menunjukan berbeda nyata pada taraf $5 \%$ menurut uji Tukey HSD

Tabel 3 menujukan bahwa hasil pengamatan rerata persentase polong bernas tanaman untuk semua perlakuan dengan berbagai konsentrasi berkisar 75,0087,66 polong. Jumlah polong pertanaman tanaman kacang hijau yang terendah pada perlakuan Abu Sekam Padi 1 ton/ha yaitu sebesar 75,00 polong, sedangkan jumlah polong tertinggi tanaman yang tertinggi diperoleh pada perlakuan Abu Sekam Padi 3 ton/ha yaitu sebesar 87,00 polong. Hal ini 
terjadi karena abu sekam padi sebanyak 6 ton/ha sudah mampu meningkatkan pertumbuhan tanaman kacang hijau. Seiring dengan ditingkatkan dosis abu sekam padi semakin meningkat juga pertumbuhan dan jumlah polong berisi pertanaman

Pembentukkan dan pengisian polong merupakan sifat yang dipengaruhi oleh genetik tanaman itu sendiri. Pemupukan yang efektif juga dapat mendorong tanaman untuk dapat tumbuh dan berproduksi secara maksimal. Untuk meningkatkan hasil produksi tanaman peranan pemupukan dalam budidaya tanaman merupakan salah satu kunci di dalam keberhasilan berproduksi (Novizan, 2002). Oleh karena itu penggunaan pupuk secara efektif harus benar- benar dipahami karena pupuk merupakan unsur hara yang diperlukan tanaman untuk tumbuh dan berkembang. Pembentukan dan pengisian polong berhubugan dengan pembungaan tanaman tersebut. Hal ini sesuai dengan pendapat Somaatmadja (1993) yang menyatakan bahwa banyaknya polong dan biji/polong terbentuk ditentukan oleh faktor pembungaan dan lingkungan yang mendukung pada saat pengisian polong. Ketersediaan unsur hara dari abu sekam padi dapat mendukung proses pembungaan tanaman. Unsur hara yang berperan dalam pembungaan tersebut adalah unsur fosfor dan kalium. Pemberian pupuk yang tepat waktu, jumlah, serta jenisnya sangat berpengaruh terhadap meningkatnya produksi.

Perbedaan ukuran biji dipengaruhi oleh faktor genetik tanaman tersebut. Hal tersebut sesuai menurut Nusifera (2000) Nusifera, S.2000. Penampilan Genetik Beberapa Karakter Daun dan Hasil 12 Kultivar Unggul Kacang Hijau pada Tiga Taraf Dosis Pemupukan Dasar N menjelaskan bahwa adanya perbedaan ukuran biji antar varietas jelas dipengaruhi oleh faktor genetik dan variasinya akan relatif konstan pada lingkungan yang bervariasi.

\subsection{Panjang Polong}

Analisis sidik ragam (Lampiran ) menunjukan bahwa perlakuan Abu Sekam Padi berpengaruh nyata terhadap panjang polong tanaman kacang hijau. Hasil uji lanjut dengan Tukey HSD taraf terkecil 5\% pengamatan panjang polong dapat dilihat pada tabel

Tabel 4 . Hasil dan Pertumbuhan Tanaman Kacang Hijau (Vigna radiata $\mathrm{L}$ ) terhadap pemberian Abu Sekam
Padi di lahan Gambut persentase polong bernas

\begin{tabular}{lc}
\hline Perlakuan & $\begin{array}{c}\text { Panjang Polong } \\
(\mathrm{cm})\end{array}$ \\
\hline Abu Sekam Padi 1 Ton/ha & $6,46 \mathrm{f}$ \\
Abu Sekam Padi 2 Ton/ha & $8,13 \mathrm{e}$ \\
Abu Sekam Padi 3 Ton/ha & $8,86 \mathrm{~d}$ \\
Abu Sekam Padi 4 Ton/ha & $9,53 \mathrm{c}$ \\
Abu Sekam Padi 5 Ton/ha & $10,23 \mathrm{~b}$ \\
Abu Sekam Padi 6 Ton/ha & $11,20 \mathrm{a}$ \\
\hline
\end{tabular}

$\mathrm{KK}=1,16$ Keterangan : angka-angka yang diikuti huruf kecil yang tidak sama menunjukan berbeda nyata pada taraf $5 \%$ menurut uji Tukey HSD

Tabel 4 menujukan bahwa hasil pengamatan rerata persentase panjang polong tanaman untuk semua perlakuan dengan berbagai konsentrasi berkisar 6,46$11,20 \mathrm{~cm}$ polong. Panjang polong pertanaman tanaman kacang hijau yang terendah pada perlakuan Abu Sekam Padi 1 ton/ha yaitu sebesar $6,46 \mathrm{~cm}$ polong, sedangkan jumlah polong tertinggi tanaman yang tertinggi diperoleh pada perlakuan $\mathrm{Abu}$ Sekam Padi 6 ton/ha yaitu sebesar 11,20 cm polong.

Kandungan unsur $\mathrm{P}$ yang ada pada abu sekam padi diantaranya posfat, Pengaruh pupuk fospat mengindikasikan perlakuan pupuk fospat sangat baik digunakan untuk menambah unsur hara tanah dalam membantu pertumbuhan tanaman. Hasil Penelitian ini sejalan dengan penelitian Bukhari (2011) tentang pengaruh pengapuran dan pemupukan fospat pada tanah yang sering tergenang terhadap pertumbuhan dan hasil kacang tanah yang menyimpulkan bahwa pemupukan $P$ berpengaruh sangat nyata terhadap panjang polong tanaman. Secara teoritis unsur fospat berdasarkan fungsinya mempunyai peranan penting dalam proses pemanjangan dan pembelahan sel, sehingga dengan tersedianya $P$ yang cukup Maka pembentukan RNA dan DNA pada inti sel tidak Terhambat

\subsection{Produksi Perplot}

Analisis sidik ragam (Lampiran ) menunjukan bahwa perlakuan Abu Sekam Padi berpengaruh nyata terhadap produksi perplot tanaman kacang hijau. Hasil uji lanjut dengan Tukey HSD taraf terkecil 5\% pengamatan panjang polong dapat dilihat pada tabel

Tabel 5 . Hasil dan Pertumbuhan Tanaman Kacang Hijau (Vigna radiata L ) terhadap pemberian Abu Sekam Padi di lahan Gambut produksi perplot 


\begin{tabular}{lc}
\hline Perlakuan & Produksi perplot \\
\hline Abu Sekam Padi 1 Ton/ha & $200,01 \mathrm{e}$ \\
Abu Sekam Padi 2 Ton/ha & $250,00 \mathrm{de}$ \\
Abu Sekam Padi 3 Ton/ha & $300,00 \mathrm{~cd}$ \\
Abu Sekam Padi 4 Ton/ha & $333,44 \mathrm{bc}$ \\
Abu Sekam Padi 5 Ton/ha & $383,35 \mathrm{ab}$ \\
Abu Sekam Padi 6 Ton/ha & $433,43 \mathrm{a}$ \\
\hline
\end{tabular}

Padi berpengaruh nyata terhadap berat 1000 biji tanaman kacang hijau. Hasil uji lanjut dengan Tukey HSD taraf terkecil 5\% pengamatan panjang polong dapat dilihat pada tabel

Keterangan : angka-angka yang diikuti huruf kecil yang tidak sama menunjukan berbeda nyata pada taraf $5 \%$ menurut uji Tukey HSD

Tabel 5 menujukan bahwa hasil pengamatan rerata persentase produksi perplot tanaman untuk semua perlakuan dengan berbagai konsentrasi berkisar 200,01-433,43. Produksi perplot tanaman kacang hijau yang terendah pada perlakuan Abu Sekam Padi 1 ton/ha yaitu sebesar 200,01 g, sedangkan produksi perplot tertinggi tanaman diperoleh pada perlakuan Abu Sekam Padi 6 ton/ha yaitu sebesar $433,43 \mathrm{~g}$

Sebagai hara penghasil energi, $P$ diserap tanaman dalam bentuk $\mathrm{H} 2 \mathrm{PO} 4$ dan dibutuhkan tanaman untuk pembentukan ATP (molekul pembawa energi) pada proses metabolisme tanaman, baik pada proses fotosintesis maupun respirasi tanaman. Unsur $\mathrm{P}$ juga merupakan bagian penting dalam fospolipid yang merupakan bagian dari membran sel, nukleotida, koenzim dan membentuk kompleks dengan gula. Dalam fase generatif (produksi tanaman), P juga merupakan komponen dari asam fitat sebagai cadangan $\mathrm{P}$ dalam biji, yaitu berupa C6H6(H2PO4)6 . Unsur P sangat berpengaruh terhadap perkembangan dan pertumbuhan tanaman, karena unsur $P$ dapat menstimulir pertumbuhan dan perkembangan akar, sehingga tanaman dapat lebih banyak menyerap unsur hara di sekitar perakaran, akibatnya pertumbuhan tanaman menjadi lebih cepat dan lebih sehat (Poerwanto dan Susila, 2014)

Unsur $P$ juga banyak terdapat dalam sel-sel tanaman berupa unit-unit nukleutida. Sedangkan nukleutida merupakan sesuatu yang mengandung $P$, sebagai penyusun RNA dan DNA yang berperan dalam sel tanaman. $P$ juga berperan untuk merangsang pertumbuhan dan perkembangan akar, sebagai bahan dasar protein (ATP dan ADP), membantu asimilasi dan respirasi, mempercepat proses pembungaan dan pembuahan, serta pemasakan biji dan buah (Mulyani, 2014)

\subsection{Berat 1000 biji (g)}

Analisis sidik ragam (Lampiran ) menunjukan bahwa perlakuan Abu Sekam

Tabel 6 . Hasil dan Pertumbuhan Tanaman Kacang Hijau (Vigna radiata $L$ ) terhadap pemberian Abu Sekam Padi di lahan Gambut berat 1000 biji

\begin{tabular}{lc}
\hline Perlakuan & Berat 1000 biji \\
\hline Abu Sekam Padi 1 Ton/ha & $60,05 \mathrm{f}$ \\
Abu Sekam Padi 2 Ton/ha & $65,01 \mathrm{e}$ \\
Abu Sekam Padi 3 Ton/ha & $67,03 \mathrm{~d}$ \\
Abu Sekam Padi 4 Ton/ha & $70,03 \mathrm{c}$ \\
Abu Sekam Padi 5 Ton/ha & $75,04 \mathrm{~b}$ \\
Abu Sekam Padi 6 Ton/ha & $80,01 \mathrm{a}$ \\
\hline
\end{tabular}

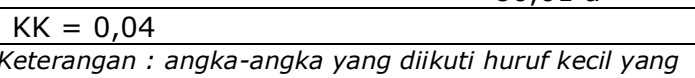
tidak sama menunjukan berbeda nyata pada taraf $5 \%$ menurut uji Tukey HSD

Tabel 6 menujukan bahwa hasil pengamatan rerata persentase berat 1000 biji tanaman untuk semua perlakuan dengan berbagai konsentrasi berkisar 60,05-80,01 g. berat 1000 biji tanaman kacang hijau yang terendah pada perlakuan Abu Sekam Padi 1 ton/ha yaitu sebesar 60,05 g, sedangkan berat 1000 biji tertinggi tanaman diperoleh pada perlakuan Abu Sekam Padi 6 ton/ha yaitu sebesar $80,01 \mathrm{~g}$

Hal ini diduga kerena pertumbuhan generatif dari tanaman kacang hijau telah mencapai pertumbuhan yang optimum. Selain itu ketersediaan air juga merupakan salah satu faktor yang menyebabkan berat dari 1000 biji kacang hijau tidak sama dengan perlakuan lainnya, dimana pada saat penelitian tanaman kacang hijau kekurangan air, sehingga menyebabkan ketersediaan air dalam tanah kurang mnecukupi untuk tanaman dalam pengisian biji. Menurut pendapat Agung dan Rahayu (2004) ketersediaan air yang cukup pada saat pertumbuhan generatif dapat meningkatkan berat biji, sebab berat biji sangat dipengaruhi oleh jumlah air yang tersedia dalam tanah

\section{KESIMPULAN DAN SARAN \\ 5.1. Simpulan}

Berdasarkan hasil penelitian dapat disimpulkan bahwa:

1. Berbagai dosis abu sekam padi yang diberikan pada tanaman kacang tanah, sudah dapat memberikan pengaruh nyata terhadap pertumbuhan tanaman kacang tanah baik pada fase 
perkembangbiakan vegetatif maupun generatif.

2. Telah dapat ditemukan perlakuan yang memberikan pengaruh terbaik terhadap pertumbuhan dan hasil tanaman kacang tanah yaitu pada dosis rata-rata 2 ton/ha dan 5 ton/ha.

\subsection{Saran}

Perlu dilakukan kajian lebih lanjut tentang penggunaan dosis abu sekam padi yang mampu meingkatkan pertumbuhan dan hasil tanaman kacang tanah di lahan gambut khususnya di Kab Indragiri Hilir

\section{DAFTAR PUSTAKA}

[1] Agung, T dan A. Y. Rahayu, 2004. Budidaya dan Analisis Usaha Tani: Kedelai, Kacang Hijau dan Kacang Panjang. Absolut yogyakarta.

[2] Atman. 2007. Budidaya dan analisis tani kedelai, kacang hijau dan kacang panjang. Penerbit Absolut. Yogyakarta. Hal : 93,94,100.

[3] Rukmana, Rahmat. 1997. Kacang Hijau Budidaya Dan Pasca Panen. Yogyakarta:

[4] Badan Pusat Statistik. 2016. Produktivitas dan Luas Panen Kacang Hijau Tahun 2015. www.bps.go. Id [7 Desember 2016].

[5] Bukhari. 2011. Pengaruh Pengapuran Dan Pemupukan Fosfor Pada Tanah Yang Sering Tergenang Terhadap Pertumbuhan Dan Hasil Kacang Tanah (Arachis hypogaea L.)

[6] Cahyono. B. 2007. Kacang Hijau. Teknik Budidaya Kacang Hijau. Tim Editor Umum. Semarang.

[7] Fadli, M, Syarini, Nina Septiani. 2015.Pengaruh Trichokompos dan Air Kelapa Terhadap Hasil Kubis Bunga (Brassica oleraceae var.botrytis L. Vol. 15 (2).

[8] Hara, Bala Fagbayide, M.G 2009. Effect of nitrogen on the growth and calyx yield of two cultivars of roselle in Northern Guinea Savanna. Middle East Journalof Scientific Research. 4. 1986. Utlization of Agrowastes for Building Materials. International.

[9] Ilyas, S. dan Sugeng P. 2000. Analisis pemberian limbah pertanian abu sekam sebagai sumber silikat pada andisol dan oxisol terhadap pelepasan fosfor terjerap dengan teknik perunut 32p. Risalah Pertemuan Ilmiah Penulisandan Pengembangan

[10] Kasno, A. 2007. Kacang hijau alternatif yang menguntungkan ditanam di lahan kering. Tabloid Sinar Tani 23 Mei 2007.
[11] Lingga P. 2007. Petunjuk PenggunaanPupuk. Penebar Swadaya. Jakarta.

[12] Marsono dan Sigit P. 2002. Pupuk Akar, Jenis dan Aplikasi. Penebar Swadaya. Jakarta.

[13] Marzuki dan Soeprapto. 2004. Perkebambahan Kacang Hijau. Penebar Swadaya. Jakarta.

[14] Mulyani, H. 2014. Buku Ajar Kajian Teori dan Aplikasi Optimasi Perancangan Model Pengomposan. Trans Info Media. Jakarta

[15] Murbandono, H. S. L. 1994. Membuat Pupuk. Penebar Swadaya.( 2005) Jakarta.40

[16] Novizan, 2002. Petunjuk Pemupukan Efektif. Agromedia Pustaka. Jakarta.

[17] Novizan. 2004. Petunjuk Pemupukan yang Efektif. Agro Media Utama. Jakarta

[18] Poerwanto, R. dan Susila, A.D. 2014. Teknologi Hortikultura. IPB Press. Bogor.

[19] Radja, R.D.D. S. Susanto. 2008. Pengaruh Pupuk Fosforterhadap Pertumbuhan Vegetatif dan Generatif Rosela 42.

[20] Rukmana. R, 2002. Budidaya kacangkacangan. Kansinus. Yogyakarta.

[21] Sabiham S, Supardi G. dan Djokodudardjo S. 1989. Pupuk dan Pemupukan. Fakultas Pertanian, Institut Pertanian Bogor. Bogor.

[22] Sabiham, S. TB. Prasetyo and S. Dohong. 2007. Phenolic Acid in Indonnesia Peat In. Rieleyand Page

[23] Setiadi. 2008. Abu Sekam Padi. Virtual Fine Art Gellry. Jakarta.

[24] Setyamidjaja Dj. 1990. Pupuk dan Cara Pemupukan. PT. Simplex. Jakarta.

[25] Somaatmadja, S. 1993. Sumber Daya Nabati Asia Tenggara 1 kacangkacangan. PT. Gramedia Pustaka utama, Jakarta.

[26] Subiksa. IGM,K. Nogroho, Sholeh and IPG. Widjaja Adhi. 1997. The Effect of

[27] Sutanto, R. 2002. Penerapan pertanian organik: pemasyarakatan dan pengembangannya. Kanisius. Yogyakarta. 219 hal.

[28] Tanah dan Iklim Indonesia. Soil and Climate Journal. No. 28:69-81.Parker, 2004. Pengantar Agronomi. Gramedia. Jakarta.

[29] Yushanita, R. M. 2007. Pengaruh Jenis Media Tanam dan Dosis Pupuk Urea terhadap Pertumbuhan Bibit Salam 